\title{
Quo Vadis, COVID-19?
}

The World Health Organization (WHO) declared a COVID-19 pandemic last March 11, 2020.,2 According to the WHO Director General, "In the past two weeks, the number of cases of COVID-19 outside China has increased 13-fold, and the number of affected countries has tripled. There are now more than 118,000 cases in 114 countries, and 4,291 people have lost their lives. Thousands more are fighting for their lives in hospitals." Soon after, Metro Manila was placed on a complete lockdown which started on March 15, 2020 and continues up to the time of this writing. ${ }^{2}$

So, what exactly is this COVID-19 pandemic? Will it be changing how we live our lives as healthcare professionals? What will be our role in taking care of patients with COVID-19? These and many other related questions require immediate answers as we face the threat of COVID-19.

The WHO was first informed of cases of pneumonia of unknown cause in Wuhan City, China near the end of 2019. A novel coronavirus was identified as the cause by Chinese authorities and was initially named 2019-nCoV., This was later revised to COVID-19 (coronavirus disease of 2019) and the virus that causes it called SARS-CoV-2 (severe acute respiratory syndrome-coronavirus 2).

In the first global epidemic caused by the "first" SARS coronavirus in 2003, the Philippines had a total of only eight confirmed patients. All the cases had contact with a nurse aide who had returned from Toronto, Canada where she got it. The index case and her father eventually died from SARS while the rest recovered. ${ }^{5}$

But, with COVID-19, at the time of writing this editorial, there were approximately 1,611 weekly cases with 112 weekly deaths in the Philippines and appears to be an increasing trend. ${ }^{6,7}$ By mid-March 2020, the WHO European Region had become the epicenter of the epidemic, reporting over 40\% of globally confirmed cases. As of 28 April 2020, 63\% of global mortality from the virus was from the Region, according to the WHO. ${ }^{3}$

There is much that we need to know about SARS-CoV-2, the virus that causes COVID-19. It belongs to the same family of coronavirus that causes SARS, MERS (Middle East Respiratory Syndrome), and even the common cold. ${ }^{3}$ Early studies report that SARS-CoV-2 was most often detected in respiratory samples from patients in China. However, live virus was also found in feces. ${ }^{8}$ It is thought that transmission mainly occurs through the respiratory route, probably as droplets, but extra respiratory sources may also be important.

Risk factors for severe illness remain uncertain but old age and comorbidities such as cardiovascular disease, liver disease, kidney disease or malignant tumors, have emerged as likely important factors. There are no proven effective specific treatment strategies, and the risk-benefit ratio for commonly used treatments such as corticosteroids is not clear. ${ }^{7,8}$ COVID-19 may also cause damage to other organs such as the heart, the liver, and the kidneys, as well as to organ systems such as the blood and the immune system. Patients die of multiple organ failure, shock, acute respiratory distress syndrome, heart failure, arrhythmias, and renal failure. ${ }^{9,10}$

Among the WHO's current recommendations, people with mild respiratory symptoms should be encouraged to isolate themselves, and social distancing is emphasized, and these recommendations apply even to countries with no reported cases.,11 However, such measures could drastically affect the economy with impact on work practices as well as commercial establishments which depend on people's patronage. . $^{12,13}$ Moreover, the psychological and mental burden that isolation and quarantine can bring about should also be considered. ${ }^{14,15}$ For those in the academe, adjustments and quick transition to online learning strategies will need to be made. ${ }^{16}$ This will also affect how scientific research is done, particularly as we try to learn more about COVID $-19 .{ }^{17}$ The longer the pandemic lasts, and the longer these measures need to be implemented, the more significant will the effects be on the economic and mental well-being of the people.

There has certainly been a rush to get more information about COVID-19. ${ }^{18}$ Although well-intended in most cases, this has resulted into an "infodemic" with some erroneous or unscientific information about COVID-19. ${ }^{19-21}$ Even mainstream scientific publications have not been spared by such faulty information. ${ }^{22,23}$ Health professionals, therefore, who will be using the information found in these publications will need to be more vigilant in making sure that the data are properly collected and interpreted. We need to constantly update ourselves as new information becomes available. ${ }^{24-26}$

As in many viral diseases, the best way to combat COVID-19 could be vaccination. Based on the experience with developing vaccines for the other coronaviruses such as the ones causing SARS, MERS and even the common colds, the development of an effective vaccine against COVID-19 may be challenging. ${ }^{27-30}$ Even if one were to be quickly developed, having the resources needed to make enough vaccines for potentially all inhabitants of our planet are also staggering. And then of course, once a vaccine is available, each country would have to device its own vaccination strategy and all of its accompanying logistic considerations. And then there is the cost of such a vaccine. As a third world country, would the Philippines be able to afford enough vaccines for its citizens?

Pending availability of an effective vaccine, one would need to look at actual treatment of COVID-19 patients. In the short-term, it may be possible to repurpose some of the currently available drugs we use for treating other viruses. ${ }^{31-33}$ In order to help address these, some wide-ranging initiatives have been set up. In March 2020, the UK Research and Innovation 
(UKRI) Medical Research Council and the UK National Institute of Health Research (NIHR) started the RECOVERY (Randomised Evaluation of COVID-19 Therapy) trial. ${ }^{34,35}$ It is the world's largest clinical trial into treatments for COVID-19, with more than 40,000 participants across 185 trials sites in the UK. It is led by the University of Oxford. At about the same time, the WHO also announced the start of an international randomized and adaptive clinical trial SOLIDARITY which will also be looking at potential treatments for COVID-19. ${ }^{36,37}$ The Philippines is set to participate in the SOLIDARITY trial. ${ }^{38}$

Use of personal protective equipment (PPEs) similar to how we have used them against Ebola and other viruses could also be beneficial. ${ }^{39}$ But similar to developing capacity for making enough vaccines, the ability to make enough PPEs, especially the disposable ones and bring these to where they are needed could also be additional challenges. In the Philippines, as in many other parts of the world, many healthcare workers report insufficient availability of PPEs which puts them at risk of getting COVID-19 from their patients. ${ }^{40,41}$

There are many more questions needing answers that we will need to deal with as we confront COVID-19. And, most likely, there will also be new challenges that can arise as the pandemic evolves. The combined efforts of the scientific and political communities will need to be engaged if we hope to successfully deal with this emergency.

\author{
Joven Jeremius Q. Tanchuco, MD, MHA \\ Professor, Department of Biochemistry and Molecular Biology, \\ College of Medicine, University of the Philippines Manila \\ Clinical Professor, Division of Pulmonary Medicine, Department of Medicine, \\ College of Medicine and Philippine General Hospital, University of the Philippines Manila
}

\section{REFERENCES}

1. WHO Director-General's opening remarks at the media briefing on COVID-19 [Internet]. 11 March 2020 [cited 2020 Apr 15]. Available from: https://www.who.int/director-general/ speeches/detail/who-director-general-s-opening-remarks-at-the-media-briefing-on-covid-19-11 -march-2020.

2. Metro Manila to be placed on 'lockdown' due to COVID-19 [Internet]. [cited 2020 Apr 15]. Available from: https://cnnphilippines.com/news/2020/3/12/COVID-19-Metro-Manilarestrictions-Philippines.html

3. Cucinotta D, Vanelli M. WHO Declares COVID-19 a Pandemic. Acta Biomed. 2020;91(1): 157-160. doi:10.23750/abm. v91i1.9397

4. Coronavirus disease (COVID-19) pandemic [Internet]. [cited 2020 Apr 15]. Available from: https://www.euro.who.int/en/health-topics/health-emergencies/coronavirus-covid-19/novelcoronavirus-2019-ncov

5. World Health Organization. SARS outbreak in the Philippines = Flambée de SRAS aux Philippines. Weekly Epidemiological Record = Relevé épidémiologique hebdomadaire. 2003;78(22):189-192. https://apps.who.int/iris/handle/10665/232177

6. COVID-19 Dashboard by the Center for Systems Science and Engineering (CSSE) at Johns Hopkins University (JHU) [Internet]. [cited 2020 Apr 19]. Available from: https://www.arcgis. com/apps/dashboards/bda7594740fd40299423467b48e9ecf6.

7. Dong E, Du H, Gardner L. An interactive web-based dashboard to track COVID-19 in real time [published correction appears in Lancet Infect Dis. 2020;20(9):e215]. Lancet Infect Dis. 2020;20(5):533-534. doi:10.1016/S1473-3099(20)30120-1

8. Murthy S, Gomersall CD, Fowler RA. Critically Ill Patients With COVID-19. JAMA. 2020;323(15):1499-1500. doi:10.1001/JAMA.2020.3633

9. Huang C, Wang Y, Li X, Ren L, Zhao J, Hu Y, et al. Clinical features of patients infected with 2019 novel coronavirus in Wuhan, China. Lancet. 2020; 395(10223):497-506.

10. Woelfel R, Corman VM, Guggemos W, Seilmaier M, Zange S, Mueller MA, et al. Clinical presentation and virological assessment of hospitalized cases of coronavirus disease 2019 in a travel-associated transmission cluster. medRXiv. March 8, 2020

11. Schmidt B, Davids EL, Malinga T. Quarantine alone or in combination with other public health measures to control COVID-19: A rapid Cochrane review. S Afr Med J. 2020;110(6): 476-477. doi:10.7196/SAMJ. 2020.v110i6.14847

12. Tandon PN. COVID-19: Impact on health of people \& wealth of nations. Indian J Med Res. 2020;151(2 \& 3):121-123. doi: 10.4103/ijmr.IJMR_664_20

13. Zouari A. What are the economic implications of COVID-19? Tunis Med. 2020;98(4):312-313.

14. Brooks SK, Webster RK, Smith LE, Woodland L, Wessely S, Greenberg N, et al. The psychological impact of quarantine and how to reduce it: rapid review of the evidence. Lancet. 2020;395(10227):912-920. doi:10.1016/S0140-6736(20)30460-8

15. Pastor, Cherish Kay, Sentiment Analysis of Filipinos and Effects of Extreme Community Quarantine Due to Coronavirus (COVID-19) Pandemic [Internet]. [cited 2020 Apr 13]. Available from: SSRN: https://ssrn.com/abstract=3574385 or http://dx.doi.org/10.2139/ ssrn. 3574385

16. A Toquero CM. Challenges and Opportunities for Higher Education amid the COVID-19 Pandemic: The Philippine Context. Pedagogical Research.2020;5(4):em0063. https://doi. org/10.29333/pr/7947

17. Center for Drug Evaluation and Research. FDA Guidance on Conduct of Clinical Trials of Medical Products during COVID-19 Public Health Emergency Guidance for Industry, Investigators and Institutional Review Boards [Internet]. [cited 2020 Apr 15]. Available from: https://www.regulations.gov/document/FDA-2020-D-1106-0002

18. Adhikari SP, Meng S, Wu YJ, Mao YP, Ye RX, Wang QZ, et al. Epidemiology, causes, clinical manifestation and diagnosis, prevention and control of coronavirus disease (COVID-19) during the early outbreak period: a scoping review. Infect Dis Poverty. 2020;9(1):29. doi:10.1186/ s40249-020-00646-x

19. Hua J, Shaw R. Corona Virus (COVID-19) "Infodemic" and Emerging Issues through a Data Lens: The Case of China. Int J Environ Res Public Health. 2020;17(7):2309. doi:10.3390/ ijerph17072309
20. Zarocostas J. How to fight an infodemic. Lancet. 2020;395(10225):676. doi:10.1016/S01406736(20)30461-X

21. Glasziou PP. A deluge of poor-quality research is sabotaging an effective evidence-based response. BMJ. 2020;369 m1847.

22. Gautret P, Lagier JC, Parola P, Hoang VT, Meddeb L, Mailhe M, et al. Hydroxychloroquine and azithromycin as a treatment of COVID-19: results of an open-label non-randomized clinical trial. Int J Antimicrob Agents. 2020;56(1):105949. doi: 10.1016/j.jiantimicag.2020.105949

23. Voss A, Coombs G, Unal S, Saginur R, Hsueh PR. Publishing in face of the COVID-19 pandemic. Int J Antimicrob Agents. 2020;56(1):106081. doi: 10.1016/j.ijantimicag.2020.106081

24. Iyer M, Jayaramayya K, Subramaniam MD, Lee SB, Dayem AA, Cho SG, et al. COVID-19: an update on diagnostic and therapeutic approaches. BMB Rep. 2020;53(4):191-205. doi:10.5483/ BMBRep.2020.53.4.080

25. Fauci AS, Lane HC, Redfield RR. Covid-19 - Navigating the Uncharted. N Engl J Med. 2020;382(13):1268-1269. doi:10.1056/NEJMe2002387

26. Dzieciatkowski T, Szarpak L, Filipiak KJ, Jaguszewski M, Ladny JR, Smereka J. COVID-19 challenge for modern medicine. Cardiol J. 2020;27(2):175-183. doi:10.5603/CJ. a2020.0055

27. Jiang S, He Y, Liu S. SARS vaccine development. Emerg Infect Dis. 2005;11(7):1016-1020. doi:10.3201/1107.050219

28. Song Z, Xu Y, Bao L, Zhang L, Yu P, Qu Y, et al. From SARS to MERS, Thrusting Coronaviruses into the Spotlight. Viruses. 2019;11(1):59. doi:10.3390/v11010059

29. Enjuanes L, Zuñiga S, Castaño-Rodriguez C, Gutierrez-Alvarez J, Canton J, Sola I. Molecular Basis of Coronavirus Virulence and Vaccine Development. Adv Virus Res. 2016; 96:245-286. doi:10.1016/bs.aivir.2016.08.003

30. McPherson C, Chubet R, Holtz K, Honda-Okubo Y, Barnard D, Cox M, et al. Development of a SARS Coronavirus Vaccine from Recombinant Spike Protein Plus Delta Inulin Adjuvant. Methods Mol Biol. 2016; 1403:269-284. doi:10.1007/978-1-4939-3387-7 14

31. Md Insiat Islam Rabby. Current Drugs with Potential for Treatment of COVID-19: A Literature Review. J Pharm Pharm Sci. 2020;23(1):58-64. doi:10.18433/jpps31002

32. Tse LV, Meganck RM, Graham RL, Baric RS. The Current and Future State of Vaccines, Antivirals and Gene Therapies Against Emerging Coronaviruses. Front Microbiol. 2020; 11:658. doi:10.3389/fmicb.2020.00658

33. Hamid S, Mir MY, Rohela GK. Novel coronavirus disease (COVID-19): a pandemic (epidemiology, pathogenesis and potential therapeutics). New Microbes New Infect. 2020; 35:100679. doi:10.1016/j.nmni.2020.100679

34. The RECOVERY trial [Internet]. [cited 2020 Apr 15]. Available from: https://www.ukri.org/ our-work/tackling-the-impact-of-covid-19/vaccines-and-treatments/recovery-trial-identifiescovid-19-treatments/

35. RECOVERY [Internet]. [cited 2020 Apr 15]. Available from: https://www.recoverytrial.net/

36. UN health chief announces global 'solidarity trial' to jumpstart search for COVID-19 treatment [Internet]. [cited $2020 \mathrm{Apr}$ 15]. Available ftom: https://news.un.org/en/story/2020/03/1059722

37. WHO COVID-19 Solidarity Therapeutics Trial [Internet]. [cited 2020 Apr 15]. Available from: https://www.who.int/emergencies/diseases/novel-coronavirus-2019/global-research-on-novelcoronavirus-2019-ncov/solidarity-clinical-trial-for-covid-19-treatments

38. PH Solidarity trial for COVID-19 treatments receives green light from ethics review body [Internet]. [cited $2020 \mathrm{Apr}$ 22]. Available from: https:/www.who.int/philippines/news/ detail/22-04-2020-ph-solidarity-trial-for-covid-19-treatments-receives-green-light-fromethics-review-body

39. Balachandar V, Mahalaxmi I, Kaavya J, Vivekanandhan G, Ajithkumar S, Arul N, et al. COVID-19: emerging protective measures. Eur Rev Med Pharmacol Sci. 2020;24(6): 3422-3425. doi:10.26355/eurrev_202003_20713

40. Philippines: Country faces health and human rights crisis one year into the COVID-19 pandemic [Internet]. [cited 2020 Apr 28]. Available from: https://www.amnesty.org/en/latest/ press-release/2021/04/philippines-faces-health-human-rights-crisis-covid/.

41. Shortage of personal protective equipment endangering health workers worldwide [Internet]. [cited 2020 Apr 15]. Available from: https://www.who.int/news/item/03-03-2020-shortageof-personal-protective-equipment-endangering-health-workers-worldwide. 